\title{
Promising Practice of Technology Integration in Math and Science Instruction: A Case of California Charter High School
}

\author{
Bobby Ojose \\ School of Education, University of Redlands \\ 1200 E Colton Avenue, Redlands, CA 92373 \\ Tel: 909-748-8810Ｅ-mail: Bobby_Ojose@redlands.edu
}

\begin{abstract}
This study was conducted to examine the promising practice of using technology in teaching math and science in a charter high school in California. The research employed an in-depth qualitative case study method. The main participants were principals, lead teachers, teachers, and support staff. Interviews, observations, and archival documents were the main data collection tools. The study found that the practice of using technology in teaching by the school, Center for Advanced Research and Technology (CART), has lead to positive educational outcomes. These include increased student achievement in standardized test scores, increased motivation, growth in mean GPA, less behavior problems from students, and improved school attendance by students. Implications for policy and practice were discussed.
\end{abstract}

Keywords: Promising practice, Teaching, Research

\section{Introduction}

This study intended to uncover the promising practices associated with technology integration, especially as they pertain to instruction of mathematics and science at the Center for Advanced Research and Technology (CART). CART is a charter high school in Fresno California. The school was authorized as a charter school in 1998 by the California Department of Education. CART is technology inclined school set up for the purpose of exposing its students to cutting edge technology that are relevant to the career chosen fields of its students. It is a half-day school program in which students can either attend it in the morning or in the afternoon after getting off their home school.

The curriculum of the CART is designed mainly around science and technology themes. The vision of the school as stated in their charter is to motivate students by creating education relevant to the workplace, with the goal of preparing students for post-secondary education and to prepare them to eventually contribute to the technology workforce (CART, 1999). To achieve this vision, the school developed curriculum that captures student interest by exposing them to a myriad of career options in medicine, technology, engineering, etc. CART help its students develop transferable skills that will prepare them to adjust to an ever-changing work environment.

CART has a population of about 1200 students and non-union faculty membership of 29 . The demographic of the school is distributed as follows: African American is 6.4\%; Asian American is 18.4\%; Hispanic is 27.2\%; White is $45.1 \%$; and other is $2.8 \%$.

Students earn credit in four classes (English, science, or social science, a career focused class, and technology) during their daily 3-hour session at CART. The curriculum in each core academic class is built upon the California State Academic Standards. All CART classes are college-prep, and most are approved and designated as meeting the University of California A-G requirements. Several technology classes prepare students to take industry certification exams, while other classes help students earn college credit through the CSU Unitrack program. In their home school, students take classes required by the State of California to graduate from high school, such as math, English, science, social science, and foreign language.

\section{Literature Review}

During the last decade, technology expenditures tripled in $\mathrm{K}-12$ schools in the United States: estimates suggest that more than $\$ 6$ billion was spent in 1999 and 2000 too old statistics! (Sivin-Kachala \& Bialo, 2000). Since no one wants these funds to be wasted, educators need insight into how to maximize the impact of their investments in technology

Many believe the recent changes in instructional technology hold great promise for revolutionizing education (David, 1994). In fact, instructional technology is often considered an important tool for bringing about the kind of systematic changes called for by those involved in reform efforts across the nation (Means, Blando, Olson, \& Middleton, 1993): 
"When computers, e-mail, and other high-tech tools are used, many educators believe, students improve their thinking skills. Teachers change the way they run their classrooms. Parents become more involved. Assessments reflect real-world activities. Children enjoy learning" (Fatemi, 1998, pp. 12-13).

Raising student achievement is a key reason districts formulate technology plans to aid instruction. For example, a study on the impact of learning technologies on student achievement in Illinois reported that scores on state assessment improved in many areas (e.g., eleventh grade science and tenth grade reading), although gains were not uniform across subject matter areas (Silverstein, Frechtling, \& Miyaoka, 2000). Swan and Mitrani (1993) also compared the interactions between (a) high school students and teachers involved in computer-based instruction and (b) those involved in traditional instruction. They found that student-teacher interactions were more student centered and individualized during computer-based teaching and learning than during traditional teaching and learning.

A number of studies have been reported that demonstrates that technology integration in mathematics and science are beneficial to the field of education. Wenglinsky (1998), of the Educational Testing Service (ETS), used data collected from the mathematics section of NAEP of 1996 and from a questionnaire completed by students, teachers, and administrators to analyze a number of different questions about computer usage in schools. Wenglinsky was particularly interested in Students' access to computer in school for mathematical tasks; students' assess to computer and frequency of computer use at home; preparedness of mathematics teachers in computer use; and the ways in which the mathematics teachers and their students use computers. (p. 80).

He found that those who used computers primarily for higher-order thinking activities did better on the mathematics section of the test than did students who used computers for other activities. In addition, he found that, in eighth grade, lower-order thinking skills were negatively related to mathematics achievement. The data seem to suggest that, if computers are to teach higher-level thinking, then students will be better mathematics students and thus earn higher achievement scores on standardized tests than if computers are not used for this purpose.

Research also suggests that students who use technology as a primary recourse are better able to understand the applications of mathematical principles (Mariotti, 2002). When students are freed to explore math through technology and a result not confined to paper and paper tasks, problems that are easy to manipulate, or workable data sets, they are able to explore rich math present in real- world math modeling. By providing a technology- rich classroom, student work is no longer limited to simple symbolic manipulation. Instead, students can interact with complex, real-world problems that enhance their understanding and pique their interest in school mathematics. The powerful influence of quality technology use in classrooms is well researched (Cuban, 2001).

While the effectiveness of computer technology on science instruction has been studied extensively, the results are inconsistent. For example, Morrell (1992) investigated whether computer-assisted instruction (CAI) would improve students' achievement scores in high school biology. Morrell found no significant difference between the means of the achievement scores of the CAI group and those of the traditional group. When Yalcinalp, Geban, \& Ozkan (1995) examined the effectiveness of using CAI for teaching the mole concept in high school chemistry, they found that students who used CAI accompanied with lectures scores significantly higher than did those who attended recitation hours, with respect to school subject in chemistry and attitudes towards chemistry subjects.

The use of technology in teaching changes the role of the teacher from that of lecturer to that of constructivist. Waxman and Huang (1996) found that instruction in classroom settings where technology was not often used tended to be whole-class approach in which students generally listened to the teacher. Instruction in classroom settings where technology was moderately used had much less whole-class instruction and independent work. Another important finding from Waxman and Huang (1996) study was that students in classrooms where technology was moderately used (more than $21 \%$ of the time) were found to be on task significantly more often than were students in other groups where technology was only infrequently used (less than $10 \%$ of the time) or in which technology was only slightly used (11\% to $19 \%$ of the time).

\section{Purpose of the Study}

The purpose of the study is to gain insight into the promising practices employed by CART in integrating technology into instruction. Even though the practice involves teaching all subjects to their students, this study is focused on the integration of technology in mathematics and science instruction. By uncovering these promising practices, it is the hope of the researcher that others can replicate them.

\section{Research Questions}

The following questions guided the study:

1) What promising practices in the area of technology does CART use to teach mathematics and science?

2) How are resources used to implement these promising practices successfully?

3) What evidence exists that the promising practices have resulted in positive educational outcomes? 


\section{Research Methods}

\subsection{Data Collection}

Data collected for the study was done through interviews, observations, and archival documents. The first method, interview, was the main data collection instrument. The researcher interviewed the principal, two lead teachers of technology, three math teachers, three science teachers and some other administrative staff connected with technology usage at CART. These were the people who were directly connected with technology integration at CART and there were four of them. The second form of data collection instrument was observations. The researcher observed mathematics and science teachers as they teach lessons. The researcher also observed a couple of professional development activities. In those observations, he was able to gain insight into what happens in the classroom that relate to technology integration. Professional development activities observation made me understood the structure, those leading, and the effect of such activities on the teachers. The third method of data collection was archival documents. The documents were obtained prior to the school visitations. They provided useful information about the school's population and demographics, status of the school, year founded, budget information, and charter. The information is necessary if one is to ascertain how long the practices of mathematics and science using technology have been in place. The document analysis enabled the triangulation of sources. Collected and analyzed were the following documents: the charter, curriculum guide, lesson plans of the teachers interviewed, and relevant student work.

Interview questions (see the Appendix) for the study were open-ended so as to allow participants the opportunity to comment about, explain, and share experiences and attitudes. The questions were developed from the research questions and therefore led fielders to say how long their practice had been in working; describe the practice of using technology in instruction; elaborate on the goals, identify the resources used; and highlight evidence indicating that what they are doing with technology is yielding positive educational outcomes.

\subsection{Data Analysis}

Because of the qualitative design of the study, data analysis came primarily from the transcripts of interviews with the principals, teachers, and the lead teachers. All interviews were taped and transcribed by the researcher. Then codes were established that corresponded with the research questions of the study. All observations and archival documents were also coded. For example, answers supplied by participants on the question of the promising practice identified the goals of the practice and stated the benefits to all stake holders (students, teachers, and parents). On the question of impact, codes that corresponded to performance on GPA, classroom behavior, constructive teaching, and higher achievement in standardized test scores were identified. On the question on resources, the following codes were identified and discussed in detail: budget information, staffing, roles of all those involved with technology, facility, and space.

\section{Findings}

\subsection{Explanation of the practice}

As stated before, CART is a charter high school that uses technology in instruction. Most of the instruction is related to projects in which the teachers finds real-life applications in which the projects that be tied. CART has technology labs that are organized into four broad career clusters that integrate math and science. A student in the engineering cluster, for example, might select biomedical engineering as a sub-focus and can use the technology lab to study the impact of poor air quality on lung capacity.

At times, the teachers collaborate in lab sessions to help students integrate all the subjects into the learning process. For example, a lesson was observed in which the class designed a plastic cup or plate with the computer and printed out the design using the three dimensional printer in the lab. Each of the three teachers in the lab had distinct roles in instruction: The physics teacher wanted them to use the computer to calculate the weight of the plastic, the chemistry teacher asked them to find the chemical compositions of various kinds of plastics and to use the computer to graph melting and viscosity rates of the plastic when exposed to heat, and the technology teacher provided them with a software package with design applications to aid them in the drawing process. At the end of the 3-hour class, most students working in groups of about four each had designed and printed out plastics from the three dimensional printer. As the chemistry teacher stated, "This kind of learning stays with the students forever" (personal interview, chemistry teacher).

\subsection{Goals of the Practice}

The goals of using technology in real-life situations and in problem-solving were addressed in detail in the interviews. The chief operating officer (COO), who is also the principal, pointed out that a major goal of using technology in teaching was to motivate and inspire students to do more than minimal work in school. According to her, the real-life application of technology helped to acquaint students with career choices that they may be interested in. She stated further that students in traditional settings, taught only through lectures and the blackboard, are less engaged in the process of learning. She noted, "They [students in traditional classrooms] do enough to pass but are not learning, so we 
are using technology in the way it is used in the world to inspire and motivate kids to learn" (personal interview, chief operating officer).

The lead teacher and network administrator (Note 1) of the school also spoke in the same vein. The network administrator thinks that the goal of the promising practice is to emulate what a business is like so that students have some real-life experience. As a result, they will not be lost when they enter the world to actually perform a job task; the exposure they received at school will help them to know what is expected of them in such an environment.

The lead teacher (who is also the dean of curriculum and instruction) also thinks that the goal is to be proficient in software use and to be able to operate in the workplace. According to him, our world is technology-based and everywhere you go ... there is specific software that's being used to advance that company in the marketplace. So we feel that the minimum technology need for our kids to get out there, they have to have their hands on a computer, know what a computer is, know how to save files, know the general logistics of navigating a computer, and know some basic applications (personal interview, lead teacher).

The goal of the promising practice as explained by the administration and staff of the school can be readily seen in the work that the students are doing in the technology labs. For example, the researcher observed the following in a class in the biomedical cluster: In a class session on calculating Body Mass Index (BMI), students were asked to offer medical advice to those sampled for the experiment. The math teacher gave the formula for calculating the BMI using the weight and height of those in the sample. The students were to use either a calculator or a computer to calculate the BMI of at least 20 people, as well as to calculate the average BMI of all those involved in the study. Next, the calculated BMI and other information pertaining to each of the subjects were entered by students into a BMI/age graph. The graph clearly illustrated to the students whose BMI was above average and thus needed a "doctor's advice." The teacher stated, "We have to expose them to things like these to have a sense of what they will be facing in the future in the medical profession" (personal communication, math teacher).

\subsection{Benefits to Students, Teachers, and Parents}

Those interviewed pointed to the benefits to using technology in teaching math and science. For example, the chemistry teacher thinks that it creates interest among the students, and it also helps them store and recall information. The teacher stated that because the students are engaged in constructive learning, they tend to be more involved, and once they learn by discovering things by themselves, they do not easily forget.

Another benefit to students is that those who might usually fear or dislike the sciences are having no such problems, as the learning is tied to real-life situations. The science teacher stated, A lot of kids come in fearful of heavy science classes such as physics and chemistry. And I think the way we teach, they say that they go back to their home school and tutor other kids. If you look at our grades, I think kids are more successful here than in traditional science course classes. (personal interview, science teacher).

The environmental science teacher thinks that the practice is very beneficial to teachers. He thinks that to have teachers of different disciplines working together is an asset. Each teacher brings his or her own perspective to the table in planning the curriculum. He commented, I think it is better for the students when teachers with different perspectives work together to plan lessons for them. Also, professionally, it is better for us; we become better teachers in seeing how other people teach their curriculum and how we could adapt some of the strategies they use into our own curriculum area (personal interview, environmental science teacher).

The network administrator thinks that the technology used by the school is good for everyone, including the parents. The technology the school uses gives parents the ability to monitor the progress of their children and wards without having to personally go to the school or make phone calls. He stated, "Students and parents can look up homework online. Parents can look up and see what their kids are supposed to be doing" (personal interview, network administrator).

\subsection{Evidence of Impact of the Practice}

According to the principal, test scores, graduation rates, and anecdotal evidence have all shown that the practice of using technology in teaching is positively impacting students' performance. When asked if the real-life situations for learning about and using technology were making a difference with or impact on the kids, she noted, we have hard data that shows that grades are higher. We have hard data which shows that kids who would never have taken physics are taking physics now. We have graduation data. We have test score data. The test scores have gone up. On the other hand, we have a lot of anecdotal data: students who have said, "I never thought I could go to college" are and now saying, "I am going." (personal interview, chief operating officer).

For example, during the 2004-2005 school year, part of CART's program evaluation effort was to compare the registration levels of sciences taken at CART to those taken at home schools. It was found that students "get immersed in sciences when they get into CART" (personal communication, chief operating officer). 
Information obtained from the school's Web site buttressed the principal's arguments that the promising practice of using technology in teaching was improving the test scores, attendance records, and cumulative GPA of the students at CART. Data reveals that the students at CART have a $98.5 \%$ rate of attendance compared to the $96.5 \%$ attendance rate at a traditional high school. (A traditional high school in this context is a non-charter school that does not use technology like CART.) According to the COO/principal, the students simply want to come to school because they know that they will not be bored with lectures. They come to be part of a student-learning-team that makes discoveries by themselves and with the help of their teachers.

Data comparing the 2003 STAR Exam scores of all students in both CART and traditional high schools showed that the mean score at CART is averaging 780, while is it a mere 650 out of the 800 maximum at a traditional high school. Again, according to those interviewed, using technology in instruction means that students are learning constructively. They are motivated. The inspiration that they get from their teachers is transferred into achievement in the form of test scores. The lead teacher commented, "I see technology as a hook for students. And with that they are motivated to learn" (personal interview, lead teacher).

The GPA of students attending CART is also increasing from year to year. Available data compared the cumulative GPA at the beginning of the school year to that at the end of the school year. There was a net gain of about 0.16 points in cumulative GPA at CART by the end of the 2004-2005 school year.

\subsection{Resource Requirements}

6.5.1 Budget information. The practice of using technology in teaching at CART requires a yearly per-student budget of about $\$ 3,800$. The director said that grants and donations of up to $\$ 8$ million were used to set up the school. The most notable donors were Intel and Microsoft. Apart from the initial exorbitant costs, software needs amount to $\$ 20,000-\$ 25,000$ per year. The school has recently embarked on a 5-year plan for technology replacement with costs of about $\$ 300,000$ a year.

6.5.2 Staffing. The staffing at CART is unique because of the structure of the program. As stated earlier, the teachers instruct their students in teams. For example, the environmental science teacher is part of a team that includes a math and an English teacher in the environmental science lab. Each of the teachers has a responsibility in teaching the math and science concepts that students need to complete assignments.

The roles of the COO/principal, the lead teacher, and the network administrator also need to be highlighted. According to the $\mathrm{COO} /$ principal, she has been involved from the very beginning. She works to obtain support from the business community in order to finance projects for the school. For example, she worked with an architectural firm to design the facility. She was also responsible for curriculum and instruction for the first 5 years before she assumed the role of a director last July.

The dean of curriculum and instruction (also known as the lead teacher) acts as bridge between the network administrator and the teachers in the school. According to him, the network administrator may not understand educational programs and the teachers do not always know how use the available technology. The lead teacher stated, "I came on board to play the in-between and find a way to make the technology work for the teachers and help them understand how to use the technology in the classroom" (personal interview, lead teacher).

The network administrator makes sure that things work for everybody in the school-teachers, students, and administrators. If students need access to a blocked Web site to complete an assignment, the network administrator unblocks it. He is also responsible for setting up the sharing of group folders. He makes sure permissions are obtained, that the Internet is always working, and that everybody has an e-mail account. According to him, "I just kind of make sure everything works, and whenever a teacher wants something or a student needs something, I just make it happen" (personal interview, network administrator).

6.5.3 Facilities and space. According to the lead teacher of technology, whoever is looking at a project like this should design "smart classrooms" like they have at CART. The smart classroom consists of a screen and a projector mounted to the ceiling that enables the teacher to connect the PC to the projector for presentations. Also, provision should be made for computer labs. Depending on the number of programs one is planning to have and the availability of funding, the lab should be cutting edge with features that enhance learning. In the labs, there should be individual computers for all students, as well as a teacher computer with a front screen, electricity backup, conference rooms, and phones. The availability of these facilities makes it easy for teachers and students to embark on the practice of using technology in teaching and learning.

\subsection{Professional Development}

Professional development activities are attended by every teacher on every Tuesday. The school started by having every teacher attends the same professional development session, but as time went on there was need to individualize the 
professional development activities. They have four or five teachers participate in a professional development activity as identified by their need, and fellow teachers present the professional development sessions. She said that it does not make any sense to force a particular training session on every teacher at the same time. She continued,

The Technology Committee plans who is presenting and what is to be presented. The Technology Committee is comprised of the principal, the lead teacher of curriculum and instruction, the lead teacher of telecommunications, and a representative of each lab. For example, the biomedicine lab is represented by the chemistry teacher, the environmental science lab is represented by the environmental science teacher, and the bioengineering lab is represented by the English teacher. Apart from deciding on the professional development presentations, the committee also decides on students' needs in the classroom. Decisions reached by the committee are disseminated to all faculty and staff. Recently, the technology committee decided that prior to purchasing any software, teachers should have an input on how they are going to use it. (personal interview, chief operating officer)

Another quality of the professional development sessions at CART is that teachers have the choice of picking two sessions from a total of four sessions. According the COO/principal, "All sessions are two hours in length. If a teacher who wants a third choice and he could not get it, we will figure out how to give him that" (personal interview, chief operating officer). She elaborated further that the reason for the choices is to give every teacher the necessary tools to effectively use technology in the classroom. It is a way of individualizing professional development and targeting the specific needs of teachers.

The teachers I interviewed explained how the professional development structure helps them in the classroom. The teachers think that to have choices in the professional development sessions is great, and even greater is the fact that fellow teachers are the presenters. The environmental science teacher shared his excitement and enthusiasm regarding professional development:

Today, for example, we have a staff development meeting with different teachers sharing lessons they use in their labs that they feel could work in other labs. Their lessons involve integration and mixing and grouping the students so they get more in different group structures and don't stay in their cliques. We've had teachers showing how they use different technology available to us to meet the standards for language arts, math, and the sciences. (personal interview, environmental science teacher)

All of the interviewees concurred that the quality and quantity of professional development provided to teachers at CART is adequate to sustain the promising practice of using technology in teaching math and science.

\section{Discussion of the Research Questions}

\subsection{What promising practices in the area of technology does CART use to teach mathematics and science?}

The CART is engaged in constructive learning because of their inclination with using technology for real-life applications in the classroom. The culture of CART cultivates an environment in which the students have the opportunity to explore and be creative in using computers for real-life situations. To help support this, the school continues to procure cutting-edge technology for their students.

The use of cutting-edge technology challenges students of CART and it offers exposure to real-world tasks that provide the students with knowledge and learning. This technique prepares the students with life-skills that go beyond classroom instructional techniques. Carswell, Thomas, and Petre (2001) suggested that the combination of an interactive learning group with challenging assignments may maximize the learning outcome. Bringing in this mode of learning while using technology to assist in skill mastery gives the student the opportunity to build more skills than what s/he would gain in a more traditional, lesson-based learning situation. One teacher affirmed by comparison, "They cover twice as much material" (personal interview, teacher).

Research by Hardwick (2000) confirmed that when students are introduced to problems relating to themselves in their world, they will feel more challenged and will commit to challenges more easily. An additional attribute of the practice is that it provides a base for student work. The real-world application gives the students the opportunity to become productive participants in the community in which they live.

In learning problem-solving skills in the computer labs, the students find the answers to the problems presented to them whether the answers come from a book, a team member, or a forum made up of staff members. Due to the flexibility of being able to learn several state-of-the-art technologies, teachers work more to facilitate rather than teach, and they are not expected to know every computer application. The learning is up to the student.

The principal/chief operating officer play a key role in establishing and maintaining a school culture that supports the integration of computer technology into the curriculum at CART. Research indicates that teachers need considerable support to integrate technology into the curriculum, including a nurturing work environment that provides opportunities for teachers to take risks and collaborate with one another (Bailey, 1996). MacNeil and Delafield (1998) argued that a faculty that becomes more comfortable with the ideas of technology will more easily integrate it into the curriculum. 


\subsection{How are resources used to implement these promising practices successfully?}

Human and material resources support the practice of the school in this study. The human resources include the teachers, lead teachers, technical support team, principal, and other staff. As was evident in the interviews, all of these people play important roles in implementing the promising practices. In addition, material resources, including the gadgets, hardware, software, and so on, are also paramount in the implementation.

The combination of both resources to enhance the practice of technology integration can be seen in their professional development activities at CART as their professional development activities are ongoing. Dexter, Anderson, \& Ronnkvist (2002) confirmed in their study that most teachers do not receive adequate instructional support for this purpose. The principals and teachers interviewed in this study, however, painted a picture of satisfaction with the training that teachers receive. This difference may be due to the fact that these are charter schools rather than public schools.

Reed (2003) asserted that professional development for teachers of pre-K-12 classrooms is important, and deemed it a critical component for the effective use of technology in the classroom. In this study, the "desk practices" (described as training of teachers by teachers), which is a component of professional development activities, have positive implications in what teachers take to the classroom from such professional development activities. CART gives a number of opportunities for professional growth by offering various professional development activities for the teachers to choose from. This model eschews the "one size fits all" approach that often discourages teachers. It also reduces the likelihood that professional development activities will be viewed as only large-scale, isolated events over which the participants have little or no control. Consequently, the problem of having little time for growth (as noted by Loucks-Horesely, 1998) is reduced.

Planning and collaboration is another way that human and technology resources have been used in enhancing the practice of technology usage described in this study. This is the case with CART; more than one teacher plans and teaches a class in a cluster. Teachers are often scared of appearing foolish or inadequately prepared by their lack of technical knowledge, but this collaboration among the teacher group serves to reduce fears related to technology use. Working with colleagues who feel comfortable highlighting student expertise can help reduce the perception that the teacher must be the expert and center of all instruction in the classroom. Collaborative efforts also serve to emphasize the benefits of technology use, which can help diminish the perception that efforts to learn a certain technology will not yield results.

\subsection{What evidence exists that the promising practice has resulted in positive educational outcomes?}

There are positive outcomes documented by the study as a result of the promising practice of using technology in teaching: Increased student achievements on standardized tests, improved school attendance, growth in cumulative GPA, and, of course, increased motivation on the part of the students to keep learning. For example, the average Academic Performance Index (API) is 780 out of the maximum of 800. Compared to neighboring schools whose score averages 650 , this is commendable. While, attributing this to technology, the principal/chief operating officer added, "parental involvement and the flexibility we have for teachers is also a factor" (personal interview, chief operating officer). The principal/chief operating officer also provided attendance records that showed that about $95.99 \%$ attendance rate is recorded daily in the school. The principal/chief operating officer also provided the researcher with the GPAs. The cumulative GPA for each grade are as follow: Grade 10 is 3.65; Grade is 3.77; and Grade 12 is 3.89. The principal/chief operating officer opined that compared to the home school of these students where average GPA is in the neighborhood of 2.50, there is reason to believe that technology integration is helping their students learn and hence the higher GPAs. The principal/chief operating officer also hinted that they do not have a dean of students to deal with discipline and incursions as behavior issues do not occur in the school. She feels that it has to do with engagement that students are put as soon as they are on campus. She said that they are motivated intrinsically by the environment. The literature is rich in evidence of technology creating all of these positive outcomes.

Those interviewed in this study believe that student learning is enhanced through the use of technology. They also expressed their belief that technology provides a critical element of preparing students for future education and employment. These beliefs are supported by large-scale research, such as that conducted by the Milken Foundation (1998). The report, "Technology in American Schools: 7 Dimensions for Gauging Progress," substantiates local teachers' perceptions that technology accelerates, deepens, and enriches basic skills ... motivates and engages students in learning ... helps relate academics to the practice of today's work force ... increases economic viability of tomorrow's workers ... strengthens teaching ... contributes to change in school ... [and] connects school to the world. (p. 43).

That teachers inherently understand and openly express their beliefs in these trends is indicative of their willingness to use technology in their instructional practice. 
There are studies consistent with the findings of this study that students' performance increases by using technology in instruction. For example: In a meta-analysis study, Christmann, Badgett, and Lucking (1997) compared the academic achievement of students in Grades 6 through 12 who received traditional instruction or traditional instruction supplemented with computer-assisted instruction (CAI) across eight curricular areas. From the 42 conclusions, they found an overall mean effect size of 0.21 , indicating that on average, students receiving traditional instruction supplemented with CAI attained higher academic achievement than did the $58.2 \%$ of those receiving only traditional instruction. They reported that their meta-analysis showed that CAI is an effective intervention for improving students' academic achievement. Christmann, Lucking, \& Badgett (1997) also contended that the result of their meta-analysis study lends support to the assumption that CAI effects vary among the different subject areas. For example, "it appears to have its strongest effect among science students; whereas its effects are weaker in mathematics, and weakest in the area of English" (p. 292).

The data in this study showed that improved student scores is only one of several ways that the promising practice of using technology in teaching has produced positive student outcomes. In CART, there has been increased attendance, fewer behavior problems, and increased motivation. Beyond the obvious benefits of promoting a familiarity with technology that will serve students in any number of current and future endeavors, proponents of technology integration cite the positive impact that instructional technology integration has on school climate and student engagement and motivation (Sivin-Kachala \& Bialo, 2000). Related research suggests that technology use has a positive impact on student attendance and drop-out rates, and also enhances feelings of independence and responsibility (Coley et al., 1997).

\section{Major Findings of the Study}

The following are the major findings of the study:

a) Teachers were more willing to be involved in the professional development activities because of the structure of having teachers lead the sessions and the room for differentiated professional growth. This is also part of the "desk practices" explained by one of the principals, which referred to the act of teachers training teachers.

b) In CART there was constructive teaching and learning due to the use of technology.

c) The promising practice of using technology in teaching led to increased student achievement at CART, as evidenced in their standardized test scores.

d) The practice has lead to other positive outcomes like increased motivation, increased attendance rate, increased mean GPA, and fewer behavior problems among students.

\section{Implications for Policy and Practice}

\subsection{Teachers}

The findings of this study are useful in several ways for a teacher who hopes to integrate technology in his or her teaching: First, the study highlighted the resources and planning that is involved in each promising practice of using technology in teaching. This information should equip teachers with the knowledge of software and hardware needs, and it should provide them with a sense of what it takes for two or more teachers to plan lessons. Second, the study highlighted what is there to be gained from using technology in teaching in the way employed by both schools in this study. For example, instead of standing in front of the class to deliver lectures (which is, by the way, more taxing), a teacher can act as a facilitator by providing activities that will enable the students to discover and construct their own learning. Also, teachers should know that it is easier to be innovative when they teach with technology than with the traditional teaching method.

\subsection{Principals}

The implication of this study for principals is in the area of resources management and professional development for teachers. Principals should understand that instructional technology integration will vary in appearance and complexity depending on a teacher's instructional and formative learning circumstances. While seemingly obvious, this becomes an important factor when creating or supporting professional growth opportunities that challenge the prescriptive nature of many professional plans and activities for instructional technology integration - an endeavor that the research suggests is often unsuccessful for any meaningful instructional change (Kimble, 1999). The understanding and support for varied types of professional growth and progress towards integrating technology could manifest themselves in supportive discussions and evaluations of teacher performance during the school year.

If principals and teachers are committed to an integrated approach for using computer technology to enhance student learning, then the issue around management and organization of computer integration needs to be embedded into the overall school plan. Principals, together with teachers, must decide the best way to integrate computer technology into the mathematics and science curriculum. 


\subsection{Policy Makers}

The implication of the findings here to district leaders and policy makers is that they must identify the need and the establish goals for using technology in teaching math and science. Next, they must consider the materials that will go into it. Following this, they must plan an improvement process and identify how and where instructional technology can support the improvement process. There also needs to be a deliberate process to measure not only the success of the curriculum but also the degree to which the available tools contribute to the success. For example, the district leaders might want to know if a particular software program is aligned with the curriculum.

\subsection{Researchers}

The data that have emerged from this study offers a foundation for building classrooms integrated with technology and demonstrates careful planning for the effective use of technology in a program aimed at raising the standards to a challenging level for students. This study indicated that students' performance and achievement improved in the case studies. However, more qualitative research should be conducted within the classroom to gather more evidence and to use the research to demonstrate the progression of learning in the technology classroom, as well as to discuss the uses of technology that support learning performance and achievement.

\section{Suggestions for Further Research}

It would be interesting to replicate this study in a traditional school system to see the other side of the spectrum: How innovative teachers and administrators at a traditional school would implement the promising practice of using technology in teaching. Also, since the research was carried out in California and is specific to California charter school, further research is recommended to investigate the practices of using technology in teaching math and science in the charter schools of other states.

\section{Refereneces}

Bailey, G. (1996). Technology leadership: Ten essential buttons for understanding technology integration in the $21^{\text {st }}$ century. Retrieved January 20, 2006, from http://coe.ksu.edu/Bailey/html/currentbuttonart.html.

Campbell, P. F., \& Stewart, E. L. (1993). Calculators and computers. In R. Jensen (Ed.), Early childhood mathematics (pp. 251-268). New York: Macmillan.

Carswell, L., Thomas, P. \& Petre, M. (2001). Distance Education via the Internet: The student experience. British Journal of Educational Technology, 31(1), 12-15.

Center for Advanced Research and Technology, (1999). Mission Statement. Retrieved May 20, 2005, from http://www.cart.org

Christmann, E. P., Lucking, R. A. \& Badgett, J. L. (1997). The effectiveness of computer-assisted instruction on the academic achievement of secondary students: A meta-analytic comparison between urban, suburban, and rural educational settings. Computers in the Schools, 13, 31-41.

Cuban, L. (2001). Oversold and underused: Computers in the classroom. Cambridge, MA: Harvard University Press.

David, J. L. (1994). Realizing the promise of technology: A policy perspective. In B. Means (Ed.), Technology and education reform (pp. 169-198). San Francisco: Jossey-Bass.

Dexter, S., Anderson, R. \& Ronnkvist, A. (2002). Quality technology support: What is it? Who has it? And what difference does it make? Journal of Educational Computing Research, 26(3), 265-285.

Fatemi, E. (1998). High tech pathways to better schools. Technology Counts 1998, a special issue of Education Week, 23-68. Retrieved July 10, 2003, from http//:www.edweek.org/sreports/tc98/.

Hardwick, S. W. (2000). Humanizing the technology landscape through collaborative pedagogy. Journal of Geography in Higher Education 24(1), 123-129.

Kimble, C. (1999). The impact of technology on learning: Making sense of the research. Aurora, CO: Mid-Continent Regional Education Laboratory.

Loucks-Horsely, S. (1998). Designing professional development for teachers of science and mathematics. Thousand Oaks, CA: Corwin Press.

MacNeil, A. \& Delafield, D. (1998, March). Principal leadership for successful school technology implementation. Paper presented at the meeting of The Society for Information Technology and Teacher Education.

Mariotti, M.A. (2002). The influence of technological advances on students'.

mathematics learning. In L.D. English (Ed.), Handbook of International Research in Mathematics Education (695-723). Mahwah, NJ: Lawrence Erlbaum Associates. 
Means, B. Blando, T., Olson, K., \& Middleton, T. (1993). Using technology to support education reform. Washington, DC: U.S. Government Printing Office.

Milken Foundation. (1998). The effect of present day technology on students' learning. Retrieved August 26, 2005, from http://www.milkenexchange.org.

Morrell, P. D. (1992). The effects of computer assisted instruction on student achievement in high school biology. School Science and Mathematics, 92(4), 177-181.

Reed, R. (2003). Streaming technology improved student achievement. T.H.E. Journal, 30(7), 14-20.Sivin-Kachala, J., \& Bialo, E. R. (2000). 2000 research report on the effectiveness of technology in schools ( $^{\text {th }}$ ed.). Washington, DC: Software and Information Industry Association.

Swan, K. \& Mitrani, M. (1993). The changing nature of teaching and learning in computer-based classrooms. Journal of Research on Computing Education, 26, 40-54.

Waxman, H.C. \& Huang, S.L. (1996). Classroom instruction differences by level of technology use in middle school mathematics. Journal of Education Computing Research, 14, 147-159.

Wenglinsky, H. (1998). Does it compute? The relationship between educational technology and student achievement in mathematics. Princeton, NJ: Educational Testing Service Policy Information Center.

Yalcinalp, S. \& Geban, O., Ozkan, I. (1995). Effectiveness of using computer-assisted instruction for teaching the mole concept. Journal of Research in Science Teaching, 32(10), 1083-1095.

\section{Appendix A}

ON-SITE LEAD TEACHER INTERVIEW PROTOCOL

School Name:

Date:

Name of Interview Subject:

Position:

Researcher:

Start Time:

End Time:

Total Time (minutes):

\section{[Introduction]}

Thank you for agreeing to meet with me. I am working with the University of Southern California's Rossier School of Education. We are studying promising practices in California charter schools. Through a nomination process, your school was identified as having success in/with [promising practice]. The purpose of this interview is to learn more about [promising practice] at your school.

The information garnered from this research will be used to develop a Web-based compendium of promising practices as part of the Multiple Measures of Accountability for California Charter Schools (MMACCS) project. The goal of the compendium is to spread new knowledge and innovation about promising practices to inspire educators to improve school performance.

By participating in this study, your school will get recognition at the annual California Charter Schools Association conference, publicity in the media, and a one-year free membership to MMACCS.

This interview should take around 45 minutes. Do you have any questions for me before we begin?

\section{A. Theory of Action and History}

1. Can you briefly describe [promising practice] at your school?

2. What is the goal of [promising practice]?

3. Please tell me about the history of [promising practice] at your school.

(Probe: How/why did it get started, who were the people initially involved in developing the practice)

4. Can you tell me a little about your role as lead teacher with respect to [promising practice]?

5. Who have been the main people involved with the planning and implementation of [promising practice]?

6. In your opinion, what factors have contributed to the successful implementation of [promising practice]?

7. How do you think that [promising practice] will lead to school improvement and higher student achievement?

\section{B. Implementation Details}

8. How long has [promising practice] been in place? 
9. How much start up/planning time was needed to implement [promising practice]?

10. How much planning time on a monthly basis is needed to maintain implementation of [promising practice]?

11. How often do you collaborate with other staff members in order to sustain [promising practice]?

12. What do you see as the next steps for ensuring sustainability of the [promising practice]?

13. How do you know [promising practice] is making a difference? [What is the evidence of impact?]

14. What are the benefits of implementing [promising practice]?

(Probes: Benefits for students, staff, administrators, parents)

15. What are the challenges of implementing [promising practice]?

(Probes: Challenges for students, staff, administrators, parents)

16. What lessons have you learned by implementing [promising practice]?

\section{Resource Requirements}

17. How much of your budget is spent on [promising practice]?

18. What is the level of staff expertise required with respect to [promising practice]?

19. What facilities are needed to carry out [promising practice]?

20. How much professional development time has staff received to implement [promising practice]?

21. Do you think the training/professional development that has been conducted meets the needs for people to effectively implement [promising practice]?

(Probe: What other types of PD do you think would be helpful to effectively implement promising practice?)

\section{Recommended Resources for Additional Information}

22. Are there any books that have been helpful to you in implementing [promising practice]?

23. Are there any articles that have been helpful to you in implementing [promising practice]?

24. Are there any Web sites that have been helpful to you in learning about [promising practice]?

25. Are there any sources of technical assistance that have been helpful to you in implementing [promising practice]?

26. Additional Comments:

\section{[Closing]}

Thank you very much for your time. Your comments and insights are invaluable for our research.

\section{Appendix B}

ON-SITE TEACHER INTERVIEW PROTOCOL

School Name:

Date:

Name of Interview Subject:

Position:

Researcher:

Start Time:

End Time:

Total Time (minutes):

\section{[Introduction]}

Thank you for agreeing to meet with me. I am working with the University of Southern California's Rossier School of Education. We are studying promising practices in California charter schools. The purpose of this interview is to learn more about [promising practice] at your school.

Through a nomination process, your school has been identified as having success in/with [promising practice]. A Web site that includes this knowledge will be developed detailing promising practices in California charter schools. The Web site is being hosted by Multiple Measures of Accountability for California Charter Schools (MMACCS) and the Center for Educational Governance.

This interview should only take 30 minutes. Do you have any questions for me before we begin?

\section{A. Evidence of Impact}

1. What has been the impact of [promising practice] on students? 
2. What has been the impact of [promising practice] on parents?

3. What has been the impact of [promising practice] on teachers?

4. What has been the impact of [promising practice] on other constituents/stakeholders (e.g. investors, community groups etc.)?

5. Was any system for measuring the success of [promising practice] adopted during the planning stages?

6. Are you aware of any research studies that confirm the impact of [promising practice] on student achievement? If yes, may we please have copies?

\section{B. Lessons Learned}

7. What benefits have you experienced as a result of implementing [promising practice]?

(Probes: Benefits for students, staff, administrators, parents)

8. What challenges have you experienced while implementing the [promising practice]?

(Probes: Challenges for students, staff, administrators, parents)

9. Have there been any efforts to improve the effectiveness of [promising practice]? If yes, explain.

10. What efforts have been made to help sustain [promising practice] at your school?

11. What future steps are needed to ensure the sustainability of [promising practice]?

12. What recommendations would you make to other educators that are thinking about adopting [promising practice]?

C. Recommended Resources for Additional Information

13. Are there any books that have been helpful to you in implementing [promising practice]?

14. Are there any articles that have been helpful to you in implementing [promising practice]?

15. Are there any Web sites that have been helpful to you in learning about [promising practice]?

16. Are there any sources of technical assistance that have been helpful to you in implementing [promising practice]?

17. Additional Comments:

\section{[Closing]}

Thank you very much for your time. Your comments and insights are invaluable for our research.

\section{Appendix C}

ON-SITE PRINCIPAL INTERVIEW PROTOCOL

School Name:

Date:

Name of Interview Subject:

\section{Researcher:}

Start Time:

End Time:

Total Time (minutes):

\section{[Introduction]}

Thank you for agreeing to meet with me. I am working with the University of Southern California's Rossier School of Education. We are studying promising practices in California charter schools. Through a nomination process, your school was identified as having success in/with [promising practice]. The purpose of this interview is to learn more about [promising practice] at your school.

The information garnered from this research will be used to develop a Web-based compendium of promising practices as part of the Multiple Measures of Accountability for California Charter Schools (MMACCS) project. The goal of the compendium is to spread new knowledge and innovation about promising practices to inspire educators to improve school performance.

By participating in this study, your school will get recognition at the annual California Charter Schools Association conference, publicity in the media, and a one-year free membership to MMACCS.

This interview should take around 45 minutes. Do you have any questions for me before we begin?

\section{A. Theory of Action and History}

1. Can you briefly describe [promising practice] at your school?

2. What is the goal of [promising practice]?

3. Please tell me about the history of [promising practice] at your school. 
(Probe: How/why did it get started, who were the people initially involved in developing the practice)

4. Can you tell me a little about your role as principal with respect to [promising practice]?

5. Who have been the main people involved with the planning and implementation of [promising practice]?

6. In your opinion, what factors have contributed to the successful implementation of [promising practice]?

7. How do you think that [promising practice] will lead to school improvement and higher student achievement?

\section{B. Implementation Details}

8. How long has [promising practice] been in place?

9. How much start up/planning time was needed to implement [promising practice]?

10. How much planning time on a monthly basis is needed to maintain implementation of [promising practice]?

11. How often do you collaborate with other staff members in order to sustain [promising practice]?

12. What do you see as the next steps for ensuring sustainability of the [promising practice]?

13. How do you know [promising practice] is making a difference? [What is the evidence of impact?]

14. What are the benefits of implementing [promising practice]?

(Probes: Benefits for students, staff, administrators, parents)

15. What are the challenges of implementing [promising practice]?

(Probes: Challenges for students, staff, administrators, parents)

16. What lessons have you learned by implementing [promising practice]?

\section{Resource Requirements}

17. How much of your budget is spent on [promising practice]?

18. What is the level of staff expertise required with respect to [promising practice]?

19. What facilities are needed to carry out [promising practice]?

20. How much professional development time has staff received to implement [promising practice]?

21. Do you think the training/professional development that has been conducted meets the needs for people to effectively implement [promising practice]?

(Probe: What other types of PD do you think would be helpful to effectively implement promising practice?)

\section{Recommended Resources for Additional Information}

22. Are there any books that have been helpful to you in implementing [promising practice]?

23. Are there any articles that have been helpful to you in implementing [promising practice]?

24. Are there any Web sites that have been helpful to you in learning about [promising practice]?

25. Are there any sources of technical assistance that have been helpful to you in implementing [promising practice]?

26. Additional Comments:

\section{[Closing]}

Thank you very much for your time. Your comments and insights are invaluable for our research.

\section{Appendix D}

CLASSROOM OBSERVATION PROTOCOL

School Name:

Date:

Teacher's Name:

Type of Class:

Time Started:

Number of Students Observed:

Lesson Topic (e.g., volcanoes, verbs):

Instructional

Goal

(e.g.,

word recognition,

comprehension): 
English $\square$ Spanish $\square \quad$ Eng/Span. Combo $\square$ Other $\square$

\section{A. Classroom Environment}

1. How does the arrangement of the room support [promising practice]?

(seating, learning centers, bulletin boards, display of student work, etc.)

2. What resources in the classroom support [promising practice]?

(presence of aids/parents, technology, books, learning manipulatives, etc.)

\section{B. Academic Lesson}

1. What is the intended purpose of the lesson?

(As written or stated by teacher-consider related standards)

2. What is the structure of the lesson?

(Whole group, small group, pairs-consider instructional time spent)

3. Explain the sequence of events and distribution of time during the lesson as it relates to [promising practice].

4. Describe the Teacher-Student interactions observed.

5. Describe the Student-Student interactions observed.

6. List (and collect copies) of pertinent resources from the lesson.

(lesson plans, handouts, teacher's guide)

Additional Notes

\section{Appendix E}

\section{PROFESSIONAL DEVELOPMENT OBSERVATION}

School Name:

Date:

\section{Professional Development Topic:}

Researcher:

Time Started:

\section{Activity Location:}

Total Time (minutes):

Number of Participants:

\section{A. Professional Development Leadership}

Who led training (check all that apply)?

\begin{tabular}{|l|l|}
\hline Teacher (from the school site) & \\
\hline Administrator (from the school site) & \\
\hline Teacher from another school & \\
\hline Administrator from another school & \\
\hline University faculty member & \\
\hline Outside consultant (describe) & \\
\hline Other (describe) & \\
\hline
\end{tabular}

1. List the names and positions of professional development session leaders:

\section{B. Professional Development Session:}

2. Describe the intended purpose of the Professional Development Session.

3. List the Agenda Items for the Professional Development Session.

(If available, include a printed copy of the agenda) 


\section{Structure of Activities during Professional Development Session}

\begin{tabular}{|l|l|}
\hline Structure & Intended Purpose \\
\hline (lecture, small group, whole group, etc.) & \\
\hline & \\
\hline & \\
\hline
\end{tabular}

4. Describe the content of the professional development session in detail:

(Probes: Key terms, theories and implementation issues related to promising practice)

5. List materials used for the professional development session

[Note: Collect all that are available]

\begin{tabular}{|l|l|}
\hline Type of Material & Description of Material \\
\hline & \\
\hline & \\
\hline
\end{tabular}

6. Additional Comments:

Notes

Note 1. The network administrator works with teachers in troubleshooting and fixing equipment and Internet-related problems and also installs math and science programs purchased by CART. 